\title{
Fungi in the respiratory tract of horses with recurrent airway obstruction
}

\author{
[Presença de fungos no trato respiratório de equinos e sua associação com \\ obstrução recorrente das vias aéreas] \\ M.O. Xavier ${ }^{1}$, C.E.W. Nogueira ${ }^{2}$, M. Meirelles $^{2}$, W.R. Fernandes ${ }^{3}$, H. Andreolla ${ }^{4}$, L.C. Severo ${ }^{5}$, \\ A.C. Pasqualotto ${ }^{4,6}$, M.C.A. Meireles ${ }^{2}$ \\ ${ }^{1}$ Universidade Federal do Rio Grande - FURG - Rio Grande, RS \\ ${ }^{2}$ Universidade Federal de Pelotas - UFPel - Pelotas, RS \\ ${ }^{3}$ Universidade de São Paulo - USP - São Paulo, SP \\ ${ }^{4}$ Santa Casa de Porto Alegre - Porto Alegre, RS \\ ${ }^{5}$ Universidade Federal do Rio Grande do Sul - UFRGS - Porto Alegre, RS \\ ${ }^{6}$ Universidade Federal de Ciências da Saúde de Porto Alegre - UFCSPA - Porto Alegre, RS
}

\begin{abstract}
This study aims to compare the concentration of viable fungi, especially those of the genus Aspergillus in the respiratory tract of stabled horses with and without Recurrent Airway Obstruction (RAO). Thirty two housed horses from four equestrian centers in Brazil were included in the study. These animals were submitted to clinical examination and to a respiratory sample collection. They were categorized into two groups: healthy and RAO-affected horses. Samples obtained by tracheobronchial washes were evaluated for fungal microscopy, quantitative culture and Aspergillus spp. quantification. Eighteen healthy and 14 RAO-affected horses were studied. Fungi were more frequently recovered in the RAO group, in comparison to controls, for both fungal microscopy $(P<0.0001)$, fungal culture $(\mathrm{P}<0.0001)$ and Aspergillus spp. quantitative culture $(p=0.001)$. In conclusion, horses with RAO have significantly higher fungal load in the respiratory tract in comparison to healthy horses. The implications of these findings in terms of the pathogenesis of RAO deserve additional investigation.
\end{abstract}

Keywords: Aspergillus, tracheobronchial washes, respiratory allergy

\section{RESUMO}

Este estudo objetivou comparar a concentração de fungos viáveis, especialmente do gênero Aspergillus, no trato respiratório de equinos estabulados com e sem obstrução recorrente das vias aéreas (ORVA). Trinta e dois equinos provenientes de quatro centros de treinamento equestre do Brasil foram incluídos no estudo. Os animais foram submetidos a exame clínico e coleta de amostra respiratória, sendo categorizados em dois grupos: sadios e ORVA. Os lavados traqueobrônquicos obtidos foram avaliados por exame micológico direto e cultivo quantitativo. Ao todo, 18 equinos saudáveis e 14 com ORVA foram estudados. Fungos foram mais frequentemente detectados em amostras do grupo ORVA em comparação com o grupo controle, tanto no exame micológico direto $(P<0,0001)$ e cultivo quantitativo $(P<0,0001)$ quanto na concentração de unidades formadoras de colônias (UFC) de Aspergillus spp. isolada em cultivo ( $p=0,001)$. Equinos com ORVA têm maior concentração de propágulos fúngicos no trato respiratório em comparação com animais sadios. As implicações desses achados na patogenia da ORVA merecem maior atenção e investigação.

Palavras-chave: Aspergillus, lavado traqueobrônquico, doença respiratória alérgica

Recebido em 20 de fevereiro de 2013

Aceito em 16 de dezembro de 2013

E-mail: melissaxavier@ig.com.br 


\section{INTRODUCTION}

Respiratory disorders, mainly recurrent airway obstruction (RAO), are one of the most important problems affecting horses maintained in stables. RAO occurs due to a hypersensitivity reaction to the inhalation of airborne allergens, which results in inflammation of the lower respiratory tract triggering mucosal edema and increased mucus production by bronchial epithelium which causes partial or complete obstruction of the airway, pulmonary wheezing, coughing, exercise intolerance and dyspnoea (Robinson and Hoffman, 2003). RAO has no predilection for gender, primarily affecting horses over eight years of age, and of sports breeds (Davis and Rush, 2002). In this context, it results in large economic losses, particularly due to the drop in performance of athletes' affected horses, and may be an impeditive factor for competition (Couetil et al., 2001).

Airborne fungi are described as one of the main groups of organisms involved in the pathogenesis of equine RAO (McPherson and Thomson, 1983; Robinson et al., 2003). The association between these fungi and the disease has been studied mostly by the quantification of specific antibodies (Halliwell et al., 1993; Kleiber et al., 2005), being scarce the data related to mycological tests in animals with and without RAO. Considering that the severity of clinical signs depends on the amount (concentration) of the allergen inhaled by the animal (McPherson and Thomson, 1983; Clarke et al., 1987), here we compared the concentration of viable fungi, especially those belonging to the genus Aspergillus, in the respiratory tract of stabled horses with and without RAO.

\section{MATERIAL AND METHODS}

The multicenter study was conducted in four Equestrian training centers in the south/southeastern Brazil, two in the state of Rio Grande do Sul (Pelotas and Porto Alegre), one in Paraná (Curitiba) and one in São Paulo (São Paulo) during the year of 2010. The project followed the ethics and animal welfare standards and received approval from the Ethics Committee of Animal Experimentation (CEEAUFPel 4749). All animals that were in participating centers during the study collection period were subjected to clinical examination and collection of epidemiological data, as well as to a single respiratory specimen collection for laboratory exams. According to the clinical examination, cytologic examination of tracheobronchial wash, and the history of previous episodes of RAO, animals were categorized into two groups: healthy horses and animals with RAO. Animals from which no respiratory specimen could be obtained and those with limited clinical data were excluded from the study, as well as horses with pulmonary hemorrhage or respiratory infection (fever and hematological parameters suggesting the presence of an infection).

Tracheobronchial washes (TBW) were collected percutaneously, after sedation of the animal (0.2 to $0.4 \mathrm{mg} / \mathrm{kg}$ of $10 \%$ Xylazine), using trocater 10 $\mathrm{Ga}$. with a catheter $12 \mathrm{Ga}$. X $70 \mathrm{~cm}$ (MILATW1228 TM). The catheter was inserted in the carina region and $100 \mathrm{~mL}$ of sterile saline solution was instilled, with immediate aspiration for the fluid recovery. After centrifugation, the TBW was submitted to cytology (stained with May-Grünwald Giemsa), as well as to mycological evaluation (microscopy and fungal culture). Fungal quantitative culture was performed by spreading $100 \mu \mathrm{L}$ of the sample precipitate on a Sabouraud dextrose agar with chloramphenicol. After seven days of incubation at $25^{\circ} \mathrm{C}$, the total number of colony forming units (CFU) was counted. Fungi were identified at the genera/species through conventional mycological methods (Larone, 2002).

The results were analyzed using SPSS 20.0, and the comparison between groups was performed using the chi-square test and Fisher's exact test for categorical variables, Mann-Whitney or Kruskal-Wallis test for quantitative variables. Pearson correlation coefficient ( $r$ ) was used to study the correlate quantitative total fungal culture (in CFU/mL) and Aspergillus spp. cultured $(\mathrm{CFU} / \mathrm{mL})$. $\mathrm{P}$ values below 0.05 were considered statistically significant.

\section{RESULTS}

The study included 32 horses, eight females and 24 males, aged between three and 23 years. Eighteen animals entered the control group and these showed no clinical and cytological abnormalities in TBW, and no previous history of respiratory disease. In the group of animals 
with RAO, 14 horses were included. All animals in the RAO group had a history of previous episodes of RAO, clinical abnormalities compatible with the illness (mucous nasal discharge, cough, dyspnoea and/or lung wheezing/rattle - at least two clinical signs typical of RAO), and/or TBW cytological change typical of the disease, as the presence of
Curshmann spirals, and increases in the number of eosinophil and/or neutrophil. All RAOaffected horses were non-febrile and showed no evidence of infection, based on blood white cell counts and serum chemistry profile. In addition, bronchoscopy was performed and showed increased mucotracheal secretions in the RAOaffected horses (Table 1).

Table 1. Clinical-epidemiological data of horses included in the study

\begin{tabular}{|c|c|c|c|c|c|c|}
\hline Horse & Gender & $\begin{array}{c}\text { Age } \\
\text { (years) }\end{array}$ & Stall & Diagnosis & $\begin{array}{l}\text { Clinical } \\
\text { signs }\end{array}$ & Fungi isolated from TBW \\
\hline 1 & $\mathrm{M}$ & 3 & Cement & Control & ND* & None \\
\hline 2 & M & NI & Cement & Control & None & $\mathrm{HF}$ \\
\hline 3 & $\mathrm{~F}$ & NI & Cement & Control & $\mathrm{ND}^{*}$ & None \\
\hline 4 & $\mathrm{~F}$ & 10 & Cement & Control & ND* & HF; Penicillium sp. \\
\hline 5 & $\mathrm{~F}$ & 6 & Cement & Control & None & Aspergillus $\mathrm{sp} . * *$ \\
\hline 6 & M & 15 & NI & Control & None & None \\
\hline 7 & $\mathrm{M}$ & NI & Cement & Control & $\mathrm{ND}^{*}$ & $\mathrm{HF}$ \\
\hline 8 & M & 11 & $\begin{array}{l}\text { Wood } \\
\text { shavings }\end{array}$ & Control & None & None \\
\hline 9 & M & 16 & Cement & Control & None & None \\
\hline 10 & M & 9 & $\begin{array}{l}\text { Wood } \\
\text { shavings }\end{array}$ & Control & None & None \\
\hline 11 & M & 7 & $\begin{array}{l}\text { Wood } \\
\text { shavings }\end{array}$ & Control & None & $\mathrm{HF}$ \\
\hline 12 & M & 21 & Cement & Control & None & None \\
\hline 13 & $\mathrm{~F}$ & 4 & Cement & Control & None & None \\
\hline 14 & M & 18 & Rice hulls & Control & $\mathrm{ND}^{*}$ & None \\
\hline 15 & $\mathrm{~F}$ & 9 & Rice hulls & Control & $\mathrm{ND}^{*}$ & $\mathrm{DF}, \mathrm{HF}$ \\
\hline 16 & M & 5 & Rice hulls & Control & None & None \\
\hline 17 & $\mathrm{~F}$ & 16 & Rice hulls & Control & $\mathrm{ND}^{*}$ & DF \\
\hline 18 & M & 6 & Rice hulls & Control & ND* & Z; DF; E. nidulans \\
\hline 19 & M & 12 & $\begin{array}{l}\text { Wood } \\
\text { shavings }\end{array}$ & RAO & ND & Z; DF; A. flavus; Penicillium sp. \\
\hline 20 & $\mathrm{~F}$ & 9 & Rice hulls & RAO & $\mathrm{ND} ; \mathrm{C} ; \mathrm{D}$ & $\mathrm{HF}$ \\
\hline 21 & M & 16 & $\begin{array}{l}\text { Wood } \\
\text { shavings }\end{array}$ & RAO & $\mathrm{ND} ; \mathrm{C} ; \mathrm{D}$ & Z; Penicillium sp. \\
\hline 22 & M & 7 & $\begin{array}{l}\text { Wood } \\
\text { shavings }\end{array}$ & RAO & $\begin{array}{l}\text { ND; C; D; } \\
\quad \text { ALS }\end{array}$ & $\begin{array}{l}\text { Z; HF; Penicillium sp.; A. flavus; Aspergillus } \\
\text { sp.** }\end{array}$ \\
\hline 23 & M & 15 & Cement & RAO & $\begin{array}{l}\text { ND; C; D; } \\
\quad \text { ALS }\end{array}$ & HF; E. nidulans; Aspergillus sp.** \\
\hline 24 & $\mathrm{~F}$ & 7 & $\begin{array}{l}\text { Wood } \\
\text { shavings }\end{array}$ & RAO & $\begin{array}{l}\text { ND; C; D; } \\
\quad \text { ALS }\end{array}$ & $\mathrm{HF}$ \\
\hline 25 & M & 14 & $\begin{array}{l}\text { Wood } \\
\text { shavings }\end{array}$ & RAO & $\begin{array}{l}\mathrm{ND} ; \mathrm{C} ; \mathrm{D} ; \\
\quad \text { ALS }\end{array}$ & HF; Penicillium sp.; A. fumigatus; A. flavus \\
\hline 26 & M & 6 & Rice hulls & RAO & $\mathrm{ND} ; \mathrm{D}$ & Z; HF; E. nidulans; Aspergillus sp.** \\
\hline 27 & M & 6 & Cement & RAO & $\begin{array}{l}\text { ND; C; D; } \\
\text { ALS }\end{array}$ & DF; HF; Penicillium sp. \\
\hline 28 & M & 23 & $\begin{array}{l}\text { Wood } \\
\text { shavings }\end{array}$ & RAO & $\mathrm{ND} ; \mathrm{C} ; \mathrm{D}$ & $\begin{array}{l}\text { DF; HF; Penicillium sp.; A. fumigatus, A. } \\
\text { flavus; Aspergillus sp.** }\end{array}$ \\
\hline 29 & M & 22 & Rice hulls & RAO & $\mathrm{ND} ; \mathrm{C}$ & $\mathrm{Z} ; \mathrm{DF}$ \\
\hline 30 & M & 17 & Rice hulls & RAO & $\mathrm{ND} ; \mathrm{C}$ & DF, HF, Penicillium sp. \\
\hline 31 & M & 10 & Rice hulls & RAO & $\mathrm{ND} ; \mathrm{C}$ & $\begin{array}{l}\text { DF, HF, Penicillium sp.; E. nidulans; } \\
\text { Aspergillus sp.** }\end{array}$ \\
\hline 32 & M & 12 & Rice hulls & RAO & ND; C; ALS & DF, HF, Penicillium sp.; E. nidulans \\
\hline
\end{tabular}

NI: No information; ND: nasal discharge; C: cough; D: dyspnea; ALS: abnormal lung sound (including lung wheeze and stertor); Z: zygomycetes (including Rhizopus sp. and Syncephalastrum sp.); DF: dematious fungi (including Alternaria, Curvularia, Bipolaris/Drechslera, Cladosporium); HF: hialohifomycetes fungi (others than Penicillium and Aspergillus, as Trichoderma sp., Paecylomyces sp.; Acremonium sp., Scopulariopsis sp., and Micelia sterila).

All RAO-affected horses but none of the controls had a history of chronic respiratory disease.

*Nasal discharge observed in the controls was of serous quality.

**Aspergillus sp: other species from the genus Aspergillus different from A. fumigatus, A. flavus, A. niger, A. terreus and Emericella 
Despite the RAO group (mean age $=12.6$ years (sd \pm 5.6 years) being slightly older than the control group (mean age $=10.4$ years $(\mathrm{sd} \pm 5.6$ years), statistical analyzes showed no significant difference between groups regarding gender $(p=0.22)$ and age $(p=0.27)$. Likewise, although in the control group $52.9 \%$ of animals were kept without bedding, in comparison to $14.3 \%$ of RAO-affected horses, there was no significant difference between groups regarding the type of bedding used (i.e., rice hulls, wood shavings or flooring cement) $(p=0.07)$ (Table 1$)$.

Mycological analyses showed that $42.3 \%$ of TBWs were positive for microscopy, showing fungal conidia and fragments of septate hyaline/dematious hyphae. This positivity was markedly different $(P<0.001)$ between groups, with rates of $6.7 \%$ in the group of healthy animals, and $90.9 \%$ in animals with RAO. Likewise, fungal concentration in TBWs in terms of $\mathrm{CFU} / \mathrm{mL}$ (including hyalohyphomycetes, zygomycetes - Mucorales - and dematiaceous fungi) differed significantly between groups
(Mann Whitney U-test, $\mathrm{P}<0.001$ ) with median of $5 \mathrm{CFU} / \mathrm{mL}$ and $310 \mathrm{CFU} / \mathrm{mL}$ in healthy and RAO animals, respectively (Figure 1).

Considering the isolation of Aspergillus species from the TBW, positive results were observed for $12.5 \%$ and $61.6 \%$ of animals included in the control and RAO group, respectively $(p=0.006)$. In the RAO group, $46.2 \%$ of TBWs grew Aspergillus sp. in concentrations of more than $100 \mathrm{CFU} / \mathrm{mL}$ (Figure 1). The comparison between the mean ranks of Aspergillus CFU/mL showed a significant difference between groups ( $\mathrm{U}$ test $=46, p=0.001$ ). Total fungal concentration in TBW correlated well with the amount of Aspergillus spp. recovered in culture ( $\mathrm{r}=0.708$; $P<0.001)$. Regarding the Aspergillus species recovered in culture, teleomorph colonies (Emericella nidulans) predominated (found in $50 \%$ of positive samples), followed by A. flavus, A. fumigatus (both found only in animals with RAO) and other distinct anamorph species (Table 1).
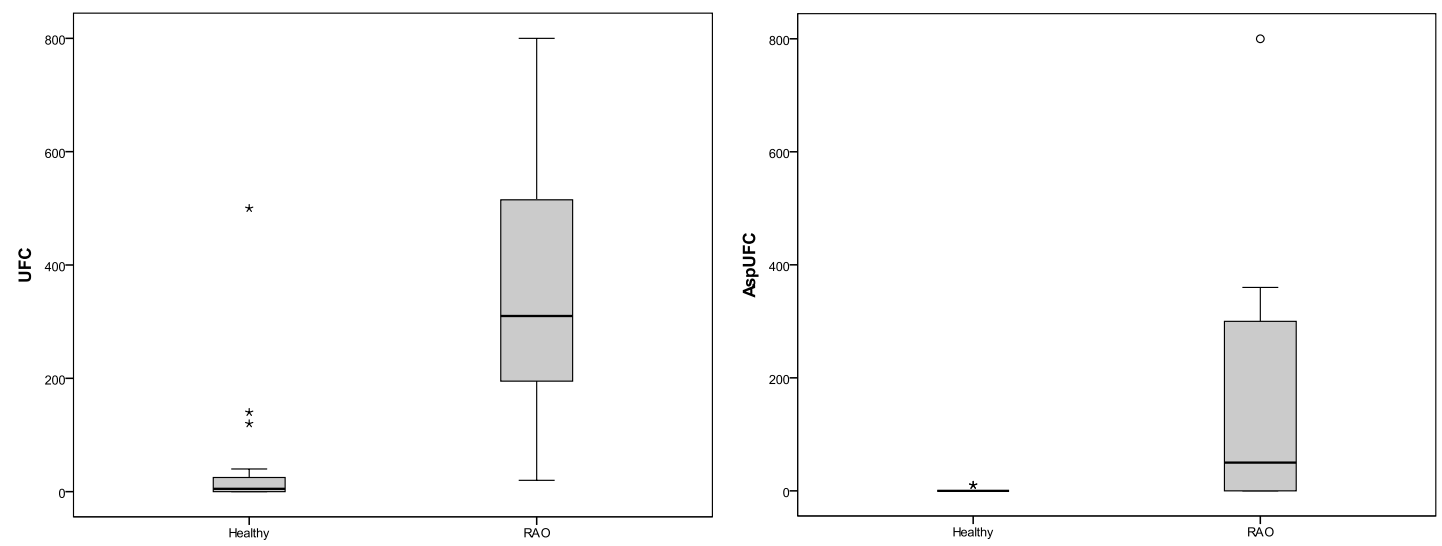

Figure 1. Total fungal CFU quantity/mL of TBW (on top) and Aspergillus spp. CFU quantity/mL of TBW (below) from 14 horses with recurrent airway obstruction (RAO) and 18 healthy control horses. RAOaffected horses had significantly higher fungal CFU/mL of TBW $(P<0.05)$ than the control horses. The middle horizontal line of the box plots marks the median of the sample. The edges of the box mark the first and third quartiles. Stars indicate outside values and circles far outside values.

\section{DISCUSSION}

Given that airborne fungi produce several known respiratory allergens (Denning et al., 2006, 2009) this study evaluated the presence of these organisms in the respiratory tract of stabled horses and its possible involvement in equine RAO. Here it was shown that a high percentage of horses $(90.0 \%)$ with RAO had positive fungal microscopy. Also, RAO-affected animals showed high concentrations of fungi in the tracheal aspirate, particularly Aspergillus species, and numbers were much higher in comparison to healthy controls. These findings corroborate with others that detected fungal particles on 
cytological respiratory samples of horses (Vrins et al., 1991; Aviza et al., 2001).

In our work, in addition to micro and macroconidia, fragments of septate hyphae were frequently observed in the TBW of horses diagnosed with RAO. Interestingly, studies call attention to the fact that the inhaled hyphae fragments have a much greater allergen potential than airborne conidia, especially given their capacity to produce numerous diffusible allergens (Green et al., 2006). It should also be noted that these structures in humans remain only in the upper portions of the airways, found mostly in samples of nasal mucosa (Green et al., 2006). Here we studied samples from the tracheobronchial region, and one might speculate that the large airway diameter in horses may allow for the detection of hyphae fragments in the lower respiratory tract. The extent at which this anatomical difference - in comparison to humans - could facilitate fungal penetration in the respiratory tract of horses to trigger a hypersensitivity reaction remains unclear and deserves further investigation.

Most of the fungi isolated from horses with RAO in this study belonged to the genera Aspergillus, Alternaria, Cladosporium and Penicillium, which allergens are well-described in the literature (Denning et al., 2006; 2009). In addition, the high positive correlation found between the amount of airborne fungi and the quantity of Aspergillus spp. in the airway demonstrates that Aspergillus spp. are the key fungi involved in fungal colonization of the respiratory tract of stabled horses, which could potentially lead to the exacerbation of the allergic response in sensitized animals. Previous studies have shown similar findings, with higher fungal concentration in animals with more severe chronic obstructive pulmonary disease (COPD), with Aspergillus as the main fungal genus isolated (Granguillot et al., 1991). However, unlike the literature that highlights A. fumigatus as the major fungal allergen (Marti et al., 2003), in our study we detected a large concentration of Emericella nidulans in clinical samples. This teleomorph species is an important etiologic agent of guturocistitis in horses (Guillot et al., 1997; Cabañes et al., 2002) and has been detected in high concentrations in stable beds of these animals, with their proliferation being favored by the urea accumulation, which the nitrogen source availability favors the conidia and the cleistothecium formation by the organism (Kosuge et al., 2000).

Previous experimental work showed that Aspergillus spp. colonization of the respiratory tract may cause hypersensitivity to ovalbumin even in individuals not previously sensitized to the protein. This may occur due to the action of proteinases produced by the fungal organisms, which exposes antigenic determinants previously sheltered. Moreover, fungi are allergen in themselves due to the glucan presence in the composition of their cell walls (Denning et al., 2006; Porter et al., 2011), and this allergenicity can also be potentiated by endotoxins commonly found in the stable's air, and therefore inhaled by housed horses (Clarke et al., 1987; Dixon et al., 1995). In this regard, although it remains unclear whether the fungal organisms are the direct cause of clinical allergic symptoms, or whether they potentiate other common allergens, the association between RAO and the presence of airborne fungi (especially Aspergillus spp.) on the respiratory tract as demonstrated in this study highlights the relevance of these organisms in the pathogenesis of the disease in horses.

Since classical mycological tests are inexpensive, easy and widely available, they could be used as a screening test to find animals with RAO that are possibly triggered by fungi. Thus, a high fungal load detected in the quantitative culture of respiratory specimens of a RAO-affected horse may be a warning for the clinician to submit the animal to more specific diagnostic investigation or also to provide them with a more targeted drug therapy. In this context, an associated antifungal therapy can play an important role in RAO clinical resolution, eliminating fungal colonization of the respiratory tract and consequently the allergen, as already demonstrated in clinical trials in humans diagnosed with allergic bronchopulmonary aspergillosis (Denning et al., 1991; Wark et al., 2004) or with severe asthma with fungal sensitization (SAFS) (Denning et al., 2009), diseases similar to equine RAO. 


\section{CONCLUSION}

The significant higher fungal load found in the respiratory tract of RAO-affected horses compared to healthy animals suggests that fungi may have a role in the pathogenesis of the disease. Also, it suggests that the mycological examination of respiratory samples should be incorporated into the routine tests performed in horses with RAO for screening to define cases possibly triggered by fungi which might guide the clinician to institute an associated antifungal therapy.

\section{ACKNOWLEDGMENT}

This work was supported by Fundação de Amparo a Pesquisa do Estado do Rio Grande do Sul (FAPERGS) grant $\mathrm{N}^{\circ} 0903328$ (ARD-003/2009).

\section{REFERENCES}

AVIZA, G.A.; AINSWORTH, D.M.; EICKER, S.W. et al. Outcome of horses diagnosed with and treated for heaves (recurrent airway obstruction). Equine Vet. Educ., v.13, p.243-246, 2001.

CABAÑES, F.J.; MONREAL, L.; MAJÓ, N.; CASTELLÁ, G. Micosis de las bolsas guturales causada por Emericella nidulans en un caballo. Rev. Iberoam. Micol., v.19, p.208-211, 2002.

CLARKE, A.F.; MADELIN, T.M.; ALLPRESS, R.G. The relationship of air hygiene in stables to lower airway disease and pharyngeal lymphoid hyperplasia in two groups of Thoroughbred horses. Equine Vet. J., v.19, p.524-530, 1987.

COUETIL, L.L.; ROSENTHAL, F.S.; DENICOLA, D.B. et al. Clinical signs, evaluation of bronchoalveolar lavage fluid, and assessment of pulmonary function in horses with inflammatory respiratory disease. Am. J. Vet. Res., v.62, p.538546, 2001.

DAVIS, E.; RUSH, B.R. Equine recurrent airway obstruction: pathogenesis, diagnosis, and pacient management. Vet. Clin. N. Am.: Equine Pract., v.18, p.453-467, 2002.

DENNING, D.W.; O'DRISCOLL, B.R.; HOGABOAM, C.M. et al. The link between fungi and severe asthma: a summary of the evidence. Eur. Respir. J., v.27, p.615-626, 2006.
DENNING, D.W.; O'DRISCOLL, B.R.; POWELL, G. et al. Randomized Controlled Trial of Oral Antifungal Treatment for Severe Asthma with Fungal Sensitization. The Fungal Asthma Sensitization Trial (FAST) Study. Am. J. Respir. Crit. Care Med., v.179, p.11-18, 2009.

DENNING, D.W.; VAN WYE, J.; LEWISTON, N.J.; STEVENS, D.A. Adjunctive therapy of allergic bronchopulmonary aspergillosis with itraconazole. Chest., v.100, p.813-819, 1991.

DIXON, P.M.; RAILTON, D.I.; MCGORUM, B.C. Equine pulmonary disease: a case control study of 300 referred cases. Part 1: Examination techniques, diagnostic criteria and diagnoses. Equine Vet. J., v.27, p.416-421, 1995.

GRANDGUILLOT, L.; FAIRBROTHER, J.M.; VRINS, A. Use of a Protected Catheter Brush for Culture of the Lower Respiratory Tract in Horses with Small Airway Disease. Can. J. Vet. Res., v.55, p.50-55, 1991.

GREEN, B.J.; TOVEY, E.R.; SERCOMBE, J.K. et al. Airborne fungal fragments and allergenicity. Med. Mycol., v.44, p.S245-S255, 2006.

GUILLOT, J.; COLLOBERT, C.; GUEHO, E. et al. Emericella nidulans as an agent of guttural pouch mycosis in a horse. J. Med. Vet. Mycol., v.35, p.433-435, 1997.

HALLIWELL, R.E.; MCGORUM, B.C.; IRVING, P. et al. Local and systemic antibody production in horses affected with chronic obstructive pulmonary disease. Vet. Immunol. Immunopath., v.38, p.201-215, 1993.

KLEIBER, C.; MCGORUM, B.C.; HOROHOV, D.W. et al. Cytokine profiles of peripheral blood and airway CD4 and CD8 T lymphocytes in horses with recurrent airway obstruction. Vet. Immunol. Immunopath., v.104, p.91-97, 2005.

KOSUGE, J.; GOTO, Y.; SHINJO, T. et al. Detection of Emericella nidulans from bedding materials in horse breeding environment and its significance as a causative agent of guttural pouch mycosis in horses. Nihon Ishinkin Gakkai Zasshi., v.41, p.251-256, 2000.

LARONE, D.H. Medically Important Fungi: A Guide to Identification, 4. ed., Washington: ASM Press, 2002. 409p. 
MARTI, E.; HOROHOV, D.W.; ANTZAK, D.F. et al. Advances in equine immunology: Havemeyer workshop reports from Santa Fe, New Mexico, and Hortobagy, Hungary. Vet. Immunol. Immunopathol., v.91, p.233-243, 2003.

MCPHERSON, E.A.; THOMSON, J.R. Chronic obstructive pulmonary disease in the horse. 1: Nature of the disease. Equine Vet. J., v.15, p.203-206, 1983.

PORTER, P.; POLIKEPAHAD, S.; QIAN, Y. et al. Respiratory tract allergic disease and atopy: experimental evidence for a fungal infectious etiology. Med. Mycol., v.49,p.S158-S163, 2011.

ROBINSON, N.E.; BERNEY, C.; EBERHART, S. et al. Coughing, mucus accumulation, airway obstruction, and airway inflammation in control horses and horses affected with recurrent airway obstruction. Am. J. Vet. Res., v.64, p.550-557, 2003.
ROBINSON, N.E.; HOFFMAN, A. Inflammatory airway disease: Defining the syndrome. Conclusions of the Havemeyer Workshop. Equine Vet. Educ., v.5, p.81-84, 2003.

VRINS, A.; DOUCET, M.; NUNEZ-OCHOA, L. A retrospective study of bronchoalveolar lavage cytology in horses with clinical findings of small airway disease. Zentralbl Veterinarmed A., v.38, p.472-479, 1991.

WARK, P.A.; GIBSON, P.G.; WILSON, A.J. Azoles for allergic bronchopulmonary aspergillosis associated with asthma. Cochrane Database Syst Rev., v.3, p.CD001108, 2004. 